\section{GELEI Andrea}

\section{HÁLÓZAT - A GLOBÁLIS GAZDASÁG KVÁZI SZERVEZETE}

A tanulmány célja, hogy értelmezze a globális gazdaság alapvetố fontosságú építóelemét, az üzleti hálózatot, majd megvizsgálja annak felépítését és múköodésének fóbb vezérlóelveit. Elóször az alapfogalmak - üzleti hálózat, ellátási lánc és ellátási háló - meghatározására és azok felépítésének bemutatására kerül sor. Ezt követóen a cikk röviden ismerteti, hogy melyek voltak azok a vállalati gazdálkodás környezetében végbement változások, melyek a gazdaság hálózatosodását elósegítették és ennek kapcsán elvezettek az üzleti hálózatok versenyképességben játszott szerepének erôsödéséhez. A szerzó ugyanakkor bemutatja a kialakuló új gazdasági modell, az ún. hálózati gazdaság múködési modelljének lényeges új tulajdonságait. A tanulmány ezután ismerteti az üzleti hálózat - $\mathrm{s}$ ezen belül az ellátási lánc - múködtetésében meghatározó koordinációs mechanizmusokban megfigyelhetố markáns változásokat. Végül részletesen ismerteti az üzleti hálózat két fớ építôelemét: a hálózatot alkotó üzleti egységeknek, illetve a közöttük kialakuló kapcsolatoknak az alapvető́ típusait.

Kulcsszavak: üzleti hálózat, ellátási lánc, koordinációs mechanizmusok, struktúra, üzleti egységek, partnerkapcsolatok

Az elmúlt évtizedekben alapvetôen megváltozott a : bement változások, melyek a gazdaság hálózatosodáát gazdaság múkködési logikája. Ma már szinte közhely nek számít, hogy nem vállalatok, hanem egymássa együttmúködő ellátási láncok, illetve hálózatok versenyeznek. Persze - mondhatja valaki - ez mindig is így volt, hiszen bármilyen termék- és szolgáltatáscsomag előállítása együttmúködő vállalatok hálózatán, illetve láncolatán keresztül jön és jött létre! Mi ebben az újdonság?

S valóban, üzleti hálózatok, ellátási láncok mindig i múködtek, s múködni is fognak. A különbség nem ezek létében, hanem kezelésük módjában található. A valóságban tehát nem is a hálózatok léte önmaǵ́ A valóságban

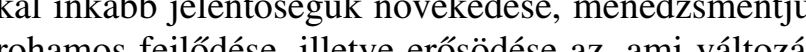
rohanos fejlósé, illetve ếsodése az, ami változás A tanulmóny célja ho my écósi gyakorlatában is. A tanulmány célja, hogy értelmezze a globális gazdaság alapvetó fontosságú epitôelemét, az úzleti hálozatot, majd megvizsgálja annak felépítését és múkōdésének fốbb vezérlōelveit. Elôször az alapfogalmak - üzleti hálózat, ellátási lánc és ellátási háló - meghatározására és azok felépítésének bemutatására kerül sor. Ezt követóen a cikk röviden ismerteti, hogy melyek voltak azok a vállalati gazdálkodás környezetében véglôsegítették, és ennek kapcsán elvezettek az üzleti háozatok versenyképességben jâtszott szerepének erősödeséhez. Bemutatom a kialakuló új gazdasági modell, az ún. hálózati gazdaság múködési modelljének lényeges uj tulajdonságait. A tanulmány ezután ismerteti az uzleti hálózat - $\mathrm{s}$ ezen belül az ellátási lánc - múködtetésében meghatározó koordinációs mechanizmusokban megfigyelhetố markáns változásokat. Végül részletezem az üzleti hálózat két fő építólemét, az üzleti hálózatot alkotó üzleti egységeket, illetve a közöttük kialakuló kapcsolatok alapvetố típusait.

Ez a gondolatmenet, az üzleti hálózatok strukturális jellegú feltárása és leírása azért is jelentős, mert a magyar gazdasági szereplók - $\mathrm{s}$ közöttük is kiemelt jelen"őségoel a hazai kis- és középvállalatok - a globalizálódó üzleti hálózatok részeként tudnak csak boldogulni. engedhetetlenül fontos ezért, hogy tisztázzuk e hálózat felépítését, építóköveit, szereplőit, s azok különbözo jellemzőit. Csak ezek ismeretében tudják a hazai, a globális verkeringésbe bekapcsolódó vállalatok valós piaci lehetôségeiket mérlegelni, versenyképes stratégiákat kialakítani és azokat az üzleti hálózat szövevényében sikeresen megvalósítani!

VEZETÉSTUDOMÁNY

\title{
Alapfogalmak
}

A végső fogyasztói igény kielégítésére alkalmas üzleti megoldäsok, konkrét termék- és szolgáltatáscsomagok mióta világ a világ üzleti partnerek együttmúködéseként jöttek létre. Ezeknek az együttmúködố partnereknek, illetve a közöttük kialakuló kapcsolatoknak a jelentősége a vállalatok versenyké pességében mára igen megnövekedt pessegen a vala ig ven mekedt, ezért elterjedt az ezek megjelöles

Léltón házat kifejezés.

Legaltaĺn lózat $-\mathrm{s}$ így az üzleti hálózat is - egy struktúra, melyben számos csomópon számos szálon keresztuil kapcsolódi egymáshoz. A csomópontok az üzlet halozatokban az egyes uzleti egysé gek, mint pl. termelő cégek, vevő́k, logisztikai vagy éppen pénzügyi szolgáltatók. Az összekötő szálak pedig e csomópontok közötti kapcsolatkén értelmezhetók. Minden üzleti hálózat-

ban mind a csomópontoknak, mind a szálaknak megvan a sajátos, speciális tartalmuk (Håkansson, 1997). Ebben a hálózatban számos esemény történik, folyamat, akció megy végbe, melyek kölcsönösen hatnak egymásra. Mind az együttmúkööó partnereknél, tehát a hálózati csomópontokon belül, mind az azok közötti együttmúködés során, a közöttïk kialakuló kapcsolatban végbemennek ilyen interakciók, kialakulnak azok komplex mintái. Így az üzleti hálózatok nemcsak kutatói koncepció szintjén léteznek, de a valóságban is megfigyelhetjük óket, mint az együttmúködő felek közötti interakcióknak szervezett mintáit (Ford et al., 2003).

A hálózat építókövei tehát az azt alkotó üzleti szervezetek, illetve a közöttük kialakuló kapcsolatok, s ezek közösségét, magát az üzleti hálózatot szokás kvázi szervezetként értelmezni (Lage - Hellman, 1996). Sót azt mondhatjuk, ez a kvái szervezt a glob́lis, gazdaśg mon

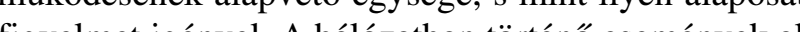
figyelmet igênyel. A hálozatban tônthó események al kítják mind az egyes részt vevó üzleti egységek, min a közöttúk kialakuló kapcsolatok tartalmát, melyek aztán adottságként, illetve eszközként a szervezete felhasználnak versenyképességüik növelése érdekében. A hálózatban éppen megfigyelhetó viszonyok mindi igen komplexek és hosszú távon alakulnak ki, adott pillanatban megfigyelhető tartalmuk a korábbi döntések, események, interakciók eredményeképpen jön létre, azokba beágyazottan jelenik meg (Hảkansson-Ford, 2002).

\section{VEZETÉSTUDOMÁNY}

Vállalat az üzleti hálózatban (Ford et al., 2003 alapján)

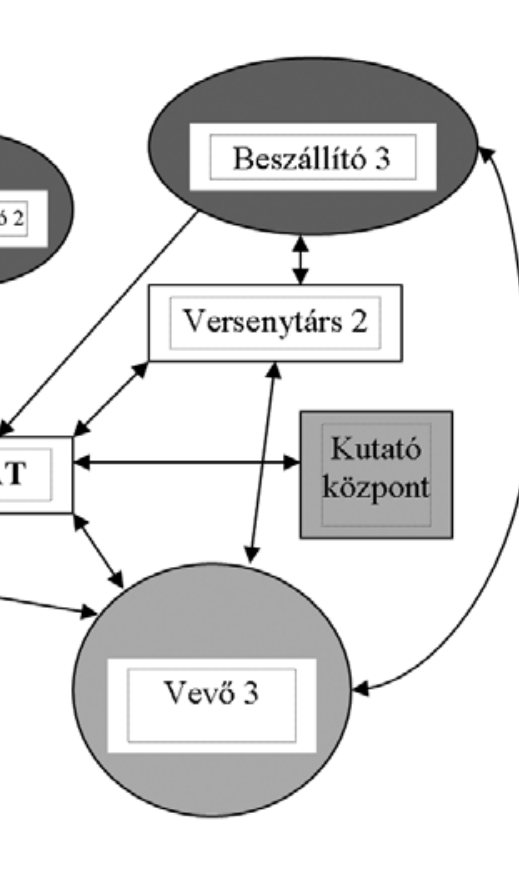

Példaként említhetiük a hazai autóipari beszállítókat (Gelei, 2007), melyben az egyik, anonimitást kéró beszállító vállalat kiemelt jelentő́ségú megrendelôjével meglévő, sikeres, bár csak egy egyszerúbb alkatrészre vonatkozó kapcsolatát arra használta fel, hogy megismerje azt a komplex modult, melybe az általa gyártott egyszerú alkatrész beépült. Az együttmúködés során az adott termékról, a modul egészéról, a gyártási technológia, $s$ végül, de nem utolsósorban a vevớról, annak igényeiról felhalmozott tudás lehetôvé tette e beszállító számára, hogy egy idô után képes legyen nemcsak az addigi termék, de a teljes modul gyártására, s ezzel a komplex modult korábban beszállító cég versenytársává nôje ki magát, megváltoztatva vevôjével meglévố kapcsolatának taralmát is.

Az üzleti kapcsolatok nagyon szorosan összefüggeA egymással, folyamatosan hatnak egymásra. Ezt az Uizleti hílózat legegyszerúbb felépítését jelentó - burmilyen három vállalat és a közötttik kiakú tét kapcsolat - púld́n is egyszeŕ belátni. A húo két kapcsolat - példán is egyszerú belátni. A három vállala (csomópont) közül bármelyi kettő közötti interakció (legyen szó akár megrendelésról, beszállításról vagy más kooperációról) eredményessége attól függ, hogy az hogyan érinti a harmadik felet, illetve a másik kapcsolatot. Amennyiben A vállalat pl. egy beszállító, B és $\mathrm{C}$ pedig két megrendelố, úgy $\mathrm{A}$ beszállító és $\mathrm{B}$ megrendelö közötti bármilyen jellegü fejlódés - $\mathrm{pl}$ a ren- 
delési volumen növekedése - negatívan vagy pozitíva is befolyásolhatja $\mathrm{C}$ vállalat múköóését (Håkansson Ford, 2002). Negatívan befolyásolhatja például, ha a rendelésnövekedés miatt a beszállító kapacitáskorlátba
iuttközik, s ezért a másik megrendeló felé a szállítandó ütközik, s ezért a másik megrendelố felé a szállítandó mennyiségeket csökkentenie kell majd. Pozitív lehet ugyanakkor, ha a rendelésnövekedés éppen ellenkezōleg, a beszállító vállalat kapacitáskihasználásának nōvekedéséhez vezet, s ezért az csökkenteni tudja árait.

Ráadásul nemcsak a hálózat adott termék- és szolgáltatáscsomagjának elóállításában közvetlenül részt vevó szereplók, illetve azok kapcsolatában bekövetkezô változások hatnak a szóban forgó szereplókre, de a hálózat bármely mús jellegú szereplói, vagy azok kapcsolatában megfigyelhetố váltoź́s is. Amennyiben-

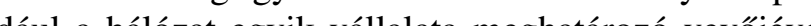

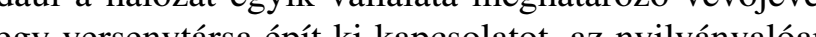
egy versentro epit ki kapcsolat, az nyilvénvalóan is (l. abra). a vizsgálat kozéppontjában alló vállalat is (1. ábra).

Az üzleti hálózat tehát állandóan fejlődô, változó, rendkívül komplex egység. Ahálózat mint teljes egység azonban - annak komplexitása, számos szereplóje és közöttük megfigyelhetố sokrétú kapcsolat, bonyolul kölcsönhatások miatt - csak igen nehezen vizsgálható. Ezért az üzleti hálózatok fogalma és vizsgálata melle elterjedt a hálózatok elterjedt a hálozato adott szempont szetett értenố leszúk vizsgálata. Az irodavizsgálata. Az irodalomban példaul elterjedt a belsó, illetve a külsố üzleti hálóza fogalma (Borbély, 2001). Belső üzlet hálózatnak tekintjük egy adott üzleti hálózatban meghatározó, központi szerepet ját-

szó, jellemzően multinacionális vállalat belsố (az anyavállalat által tulajdonolt) szervezeti egységeit, illetve a közöttük lévő kapcsolatokat. Külső üzleti hálózat pedig e vállalat, illetve vállalatcsoport körül létrejövő közvetlen beszállítók, a nemzetközi vállalat termékeinek értékesítésére szerveződött, de attól független szervezeteket és azok további kapcsolatrendszerét.

$\mathrm{Az}$ üzleti hálózatok egy másik szempont szerin történő leszúkített, de hatékony elemzési lehetőséget biztosító értelmezését adja az ellátási lánc fogalma. Az ellátási lánc fogalmának értelmezése, illetve meghatározása során ugyanakkor érdekes módon két megközelítessel is találkozhatunk. Az egyik ellatásilanc- értelmezés szerint az nem más, mint három vagy több egységból (szervezet vagy egyén) álló csoport, mely tagjai kozvetlenül részt vesznek meghatározott termék-és szolgáltatáscsomag kapcsán szükségessé váló, a forrástól a végsó felhasználás felé irányuló termék-, szolgáltatás-, információ-, pénz- és értékáramlás biztositásában (Mentzer et al., 2001). Érdekes, hogy az ellátási lánc ilyen módon történő értelmezése a lánc szereplőire, tehát az üzleti hálózat egyik egységére, a csomópontra helyezi a hangsúlyt, de nem hangsúlyozza a másik építőelemet, a szereplók közötti kapcsolatokat Az ellát́si lánc tipikus szereplói, az ún. központ vallatar az a lzerpló, akinek a szenpoujubozpont

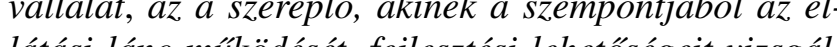
latasi lan mukbdeset, fejleszlesi lehetósegeit vizsgáljuk, s aki az egesz valtozas motorja. Az ellátási lánc központi vállalata jellemzôen erôs, a végsố fogyasztói értékteremtésre alkalmas termék- és szolgáltatáscsomag előállításában központi szerepet játszó, gyakran nemzetközi nagyvállalat. További szereplók az első-, másod- stb. körös beszállítók, beleértve a végsô, jellemzóen alapanyag-beszállítókat illetve a közvetlen, elsôkörös, illetve a közvetett megrendelók, beleértve a végsố fogyasztót. Az ellátási lánc jellegzetes szereplôi továbbá a logisztikai szolgáltatók, illetve a termékfejlesztésben részt vevố kutatóintézetek is (2 ábra). (Gelei, 2008; in: Demeter és szerzôtársai, 2008 alapján)

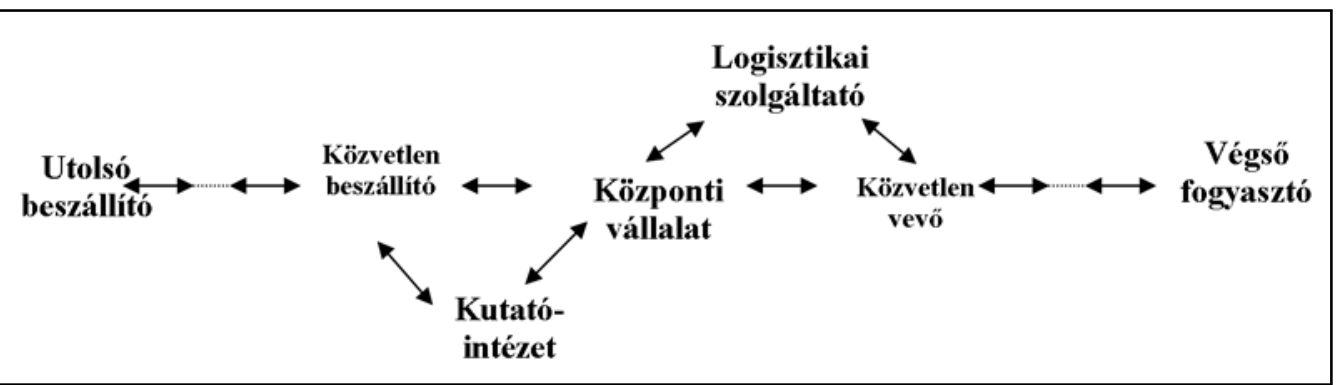

Az előzőek szerint értelmezett, tehát az ellátási lánc zereplőire hangsúlyt helyezô ellátási lánc valójában azonban szintén nem láncszerú felépítést mutat, sokkal inkább egy fa törzsére, gyökereire és ágaira emlékeztet, ezért gyakorlatilag az ellátási lánc fogalmával azonos tartalommal szokás az ellatási háló kifejezést is használni (3. ábra).

Az ellátási lánc - az egyik értelmezés szerint tehát - a szereplóket hangsúlyozza, helyezi az értelmezés középpontjába. Egy másik megközelítés szerint az ellátási láncot úgy értelmezzük, mint adott termék- és szolgáltatáscsomag létrehozásához szükséges értékteremtó folyamatok együttmúködố szervezeteken átívelố

Az elátási háló fára emlékeztetố struktúrája

(Lambert - Cooper, 2000)

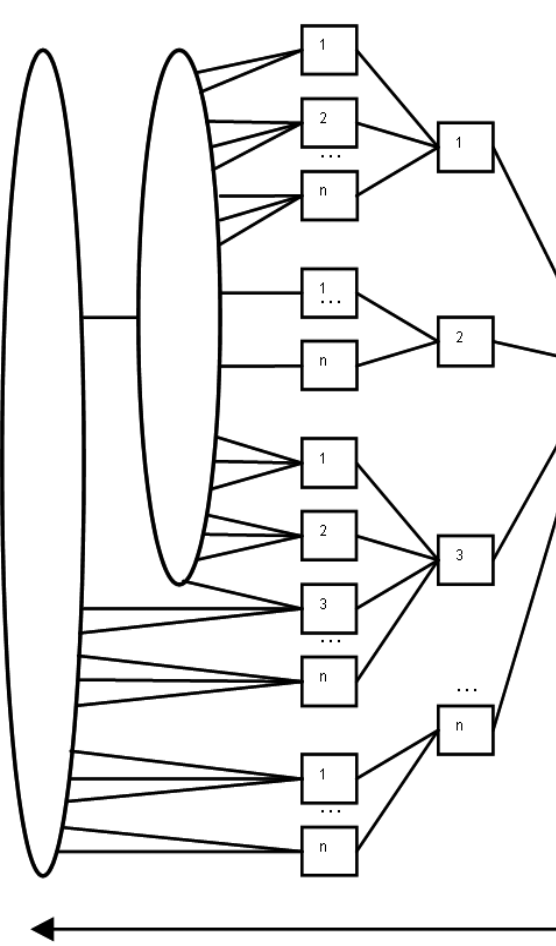

Beszállitók

sorozata, mely vevói igények kielégitésére alkalmas terméket, illetve szolgáltatást hoz létre (Chikán, 1997). Ez a definíció az elemzés középpontjába azokat az é tékteremtő folyamatokat helyezi, melyeken kereszt a végsố fogyasztó igényének kielégítéséhez szükséges üzleti megoldás létrejön, realizálódik. Az ellátási láncban végbemenó kulcsfontosságú folyamatok a következók (Lambert - Cooper, 2000):

- vevókapcsolat menedzsmentje (CRM),

- vevói szolgáltatások menedzsmentje,

keresletmenedzsment,

komplex rendelésteljesítési folyamat,

- termelési folyamatok átfogó menedzsmentje,

- beszerzési folyamatok átfogó menedzsmentje.

komplex termékfejlesztés,

visszutas folyamatok menedzsmentje.

Ezek a kulcsfontosságú folyamatok az adott üzle hálózat, azon belül a konkrét ellátási lánc felépítésétố függóen igen sokféleképpen valósulhatnak meg. Mindig önálló döntés, illetve döntések sorozataként alaku ki, hogy az említett kulcsfolyamatok mely része, mely ellátásilánc-szereplóhöz kerül. A fogyasztói igény kielégítése szempontjából meghatározó jelentőségú, az egyes együttmúködó szervezeten belül megvalósuló

\section{VEZETÉSTUDOMÁNY}




\section{Az ellátási lánc folyamatainak tipikus felépítése} (Lambert - Cooper, 2000 alapján)

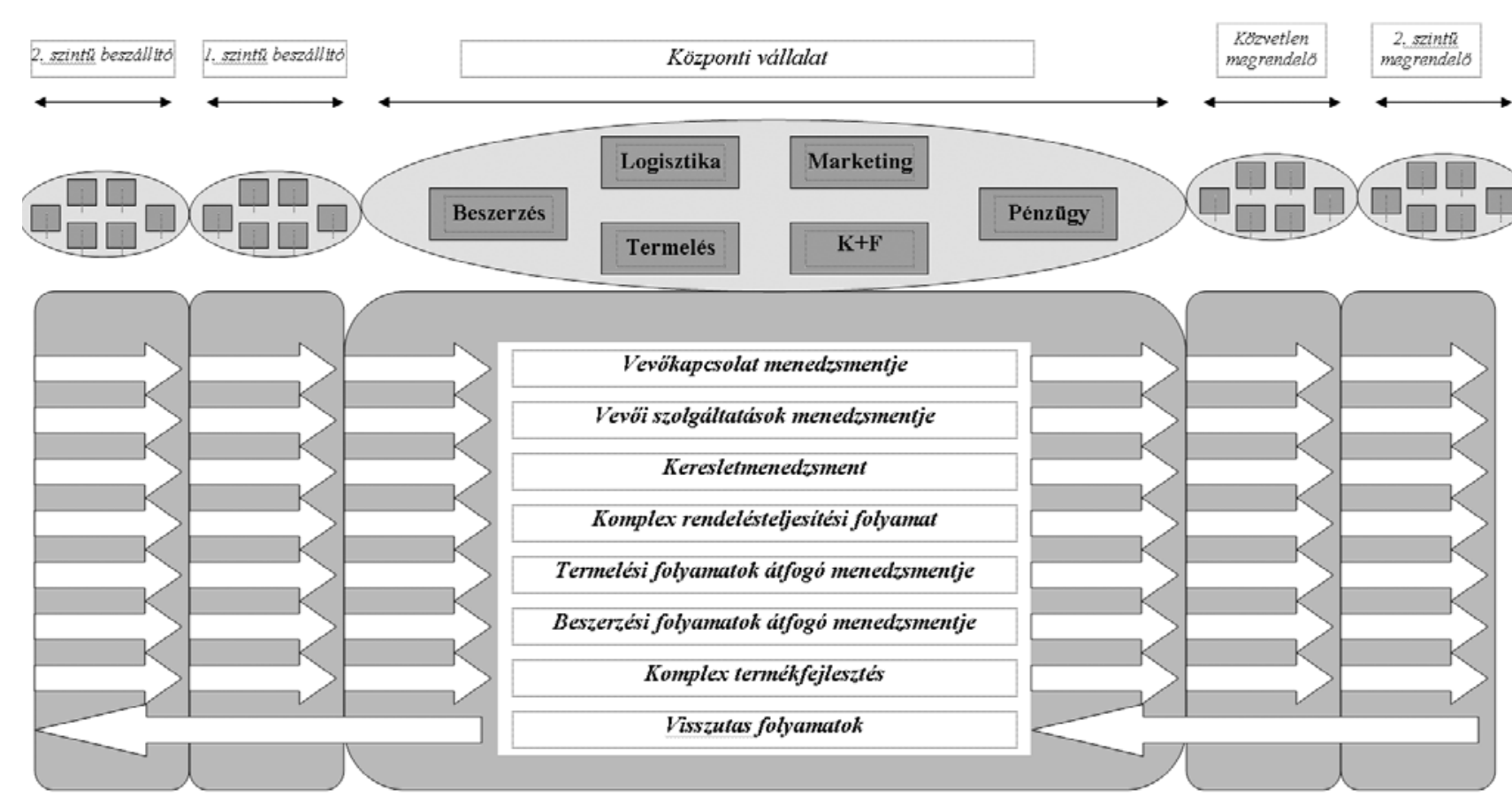

szokás szervezeti határokon zajló vagy szervezeti határokat feszegető tevékenységeknek (boundary spanning rokat feszegetó tevékenységeknek (boundary spanning lék lehetnek, ide tartozik például egy kutatás-fejlesztési folyamatban a központi vállalat mérnökének a beszállító vállalatnál végzett tanácsadói, támogatói munkája, vagy a beszállító vállalat mérnökeinek ismeretszerzó tevékenységei, melyet a központi vállalat termelési rendszerének, alkalmazott technológiájának alaposabb megismerése érdekében a központi vállalatnál fejtenek ki, vagy például a központi vállalat beszerzési speciaistájának a beszállító beszállitójánál végzett beszállító értékelést segítő tevékenysége.

A cikk foglalkozott az üzleti hálózat, az ellátási háló és az ellátási lánc fogalmaival, ami új, nem is ezek léte, mint inkább menedzs ellátási lánc menedzsmentjét is úgy hatúrozhatjuk meg. mint az abban részt vevó szervezetek, illetve a közöttik zajló folyamatok tudatos, a résztvevók versenjoépessegének javítast ćlzo kezelését (Gelei, 2003 apsen). E konkrét Ezzon mónon, színes eszkōztár alkalmazásával valósulhat meg, min egyikben közös ugyanakkor, hogy a hálózatban, illetve az ellátási láncban egyúttmúködó partnerek kozòs, összehangolt erôfeszítéseket tesznek annak érdekében, hogy az így kialakuló együttmúködésben részt vevor vállalati kör versenyképessége növekedjen.

\section{A hálózati múkködési modell kialakulása}

Az üzleti hálózatok szerepének erősödését alapvetően befolyásolta néhány, a vállalati múködés környezetében végbement változás. Ezek közül kiemelkedô jelentốségú a nemzetközi verseny szempontjából meghatározó vállalatok múködésének nemzetköziesedése, illetve globalizációja; az a tény, hogy mind a tágan értelmezett eróforrás, mind a felvevốpiacok esetében a versengố vállalatok globális piaccal találják szemben magukat. E vállalatok számára versenyképességük megörzése, illetve növelése szempontjából életbevágóan fontos kérdéssé válik e globális piacok elemzése, értékelése és a közöttük történő választás, majd az így kialakuló komplex, jellemzón több nagy nemzetközi régión átivomptékteremtő folyamatok hatékony menedzsmentje.

Míg a globalizáció szükségessé, addig az ezzel nagyjából párhuzamosan végbemenő fejlớdés az ún. idó- és térzsugorító technológiákban (Dicken, 2003) - azaz az információs technológiában és a logisztikai folyamatok megvalósításában - megfigyelhetó erôteljes fejlódés lehetővé tette a kialakuló komplex, nemzeti határokon, sốt földrészeken átívelő bonyolult folyamatok hatékony kezelését.

A globális múködés, az ezeket támogató modern információtechnológiai eszközök alkalmazása, a vele járó komplex üzleti hálózatok múködtetése, komplex logisztikai szolgáltatások kialakítása és biztosítása igen tóke- és tudásigényes, melynek biztosítása a korábban oly meghatározó múködési keretek között egyre kevésbé volt hatékonyan megvalósítható. Ennek az összetet múködésnek a megvalósítása ezért jellemzően együtt ját a korábban adott vállalat határain belül megvalósított tevékenységek erôteljes kiszervezésével és ezzel a vállalat múködés hálózatosodásának erősödésével (Gelei, 2003).

A vertikálisan integrált nagyvállalati modell erốteljes tevékenységkoncentrációval ja KÖZPONTI VÁLLALAT

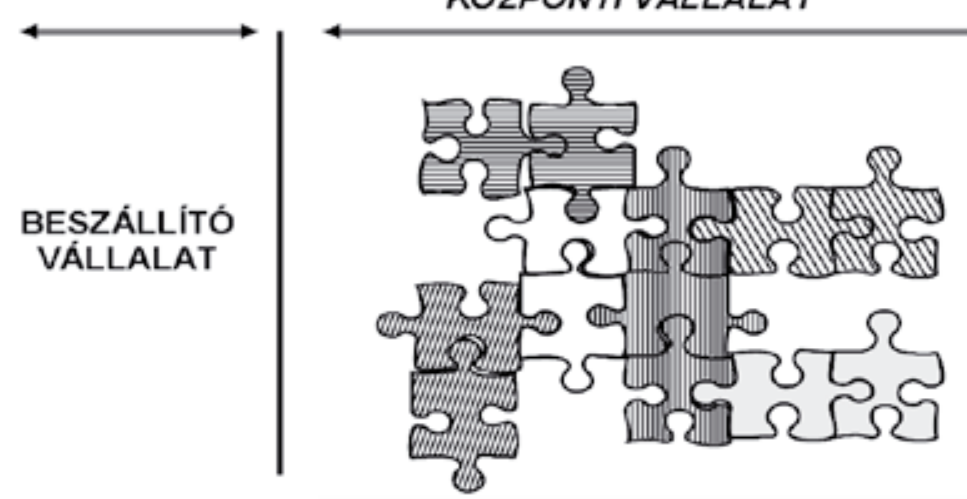

Disztribuciós
logisztikai
tevékenysegegek MW

\section{Óssi} Ėrtékesitési
tevékenységek umkezelési feladatokat (mely a nemzetköziesedéssel onmagában is egyre bonyolultabbá válik), de például a hatékony raktármúködtetési, információnyújtási képességet s értéknövelố szolgáltatások széles körének nyújtasat is igényli (Shary - Sko/tt-Larsen, 2001). Ezeket z összetett - tudás és tókeigényes folyamatokat - a vállalatok jellemzően már nem saját szervezeti keretek között valósítják meg, inkább külső specialistára bíz-

5. ábra zák. Így alakulnak ki a ma már ismert $3 \mathrm{PL}$ illetve 4 PL logisztikai szolgáltatók, melyek a megrendeló vállalat lentôs részét kezelik, vagy éppen a teljes ellátási lánc logiszti-

A hagyományosnak tekinthetố, vertikálisan integrált vállalati múködési modell (5. ábra) esetében a vállalat vezetése törekedett arra, hogy versenyképességét alapvetóen meghatározó tevékenységeit házon belül tarthassa, hiszen annak irányítása és ellenôrzése így hatékonyan biztosíthatónak túnt. Ez természetszerúen hozta magával, hogy az e múködési modellben is meglévő partnerkapcsolatok jellemzóen kis jelentőségüek, a vállalat együttmúködố partnerektôl való függốsége jellemzóen alacsony fokú, ezek a kapcsolatok megh tározóan rövid távúak és az együttmúködő partnerek viszonylag könnyen lecserélhetók. A vállalatvezetés figyelmének középpontjában a vállalaton belüli folyafigyelm ek kozen lesserelhetok. A vallalarvezeles tekintenek úgy, mint a versenyelőny megszerzésének tekintenek úgy,
fontos forrásár

A globalizációt az említett okok miatt kísérô erôtel-
forán forra. jes kiszervezési hullám együtt jár a vállalatok versenyképességét közvetlenül és erôteljesen érintoó tevékenységek kiszervezésével. A globális múköodés logisztika folyamatai például rendkívül összetettek, magukba foglalják nemcsak az áru megadott célállomásra történô eljuttatását és az ezzel osszekapcsolódó dokumen- 
a korábbi, hagyományos múködési módnál hangsúlyosabbá válik a vállalati, szervezeti határokon átnyúlo folyamatok megfelelő kezelése, tehát az ellátási lán hatékony menedzsmentje (6. ábra).

Az ún. hálózati múködés

megosztott folyamat-, illetve tevékenységstruktúrája

KÖZPONTI VÁLLALAT
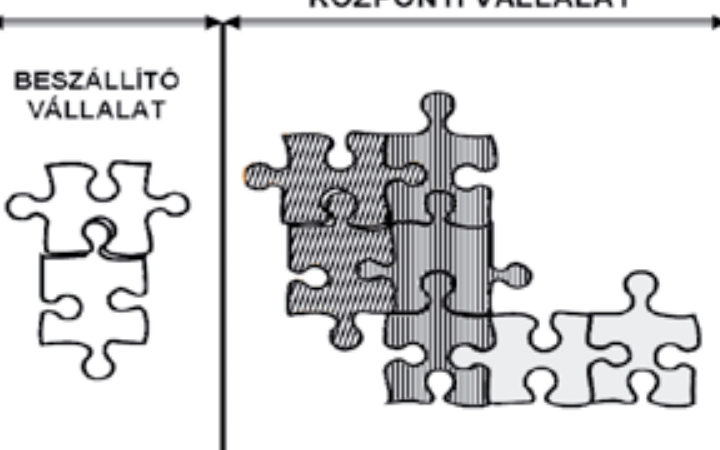

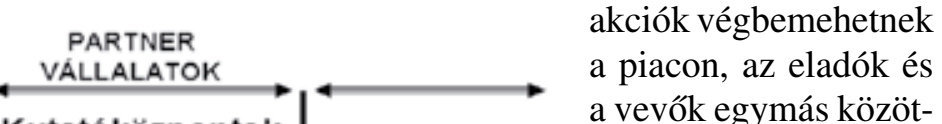

Kutatóközpontok MEGRENDELÓ ti ügyletei formájában

VÁLLALAT (a termék tulajdon(a tén ándonjogának átadásával)

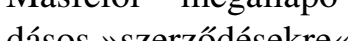
dâsos »szerzôdésekre« kerülhet sor a formalis szervezeteken, vállalati hierarchikus struktúrákon belül, mégpedig a menedzseri ... utasítások révén" (idézi Tari, 1998: 27. old.). A tranzakciós költségek elmélete gyakor-

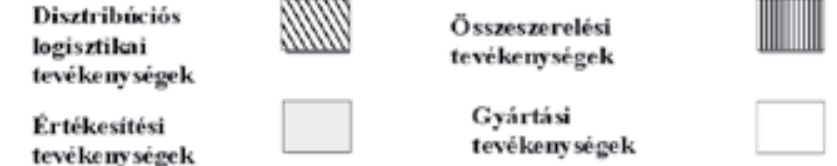

tevékenysigek

A vevői igényeket kielégitố termék- és szolgéltatáscsomag létrehozása mögött meghúzódó ellátás

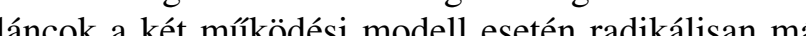
tevékenységmegosztással jellemezhetốk, s ez alapvető változást hozott a hálózat, illetve az ellátási lánc, óket alkotó partnerkapcsolatok kezelésében is. E változások közül a következókben kiemelten tárgyalja a cikk a hálózat felépítését befolyásoló koordinációs mechanizmusokat.

Változások a koordinációs mechanizmusokban

A koordinációs mechanizmus fogalma alatt a társadalmi tevékenységcsere végrehajtását irányító alapelvek és szabályok összességét értjük (Chikán, 2004). E társadalmi tevékenységcsere koordinációs mechaE társadalmi tevérenysecser nizmust most leszllito illetve ezen belnt az ellatasi lancokban együttmúköo vallalatok kozon vegbemenó tranzakciok iranyítasi alapelveiben, illetve eszközrendszerében megfigyelhe to valtozasok szemponjabol targyaljuk. Arra vagyunk kíváncsiak, hogyan változott meg a hálózati múködés modellben, illetve az ellátási láncokban együttmúköd vállalatok között e termék- és szolgáltatáscsere irányításának eszköztára

A tranzakciós költségek elmélete (Coase, 1937, Williamson, 1975) az együttmúködő partnerek (alap- illetve a bürokratikus koordinációs eszközök szerepének leértékelôdésével. Vajon tényleg ez figyelhetô meg?

A koordinációs mechanizmusok vizsgálata során kialakuló kép korántsem írható le ilyen egyszerúen. Bár a hálózati múködési modell kialakulása nagyrészt éppen azzal magyarázható, hogy a globális múködés igen tốkeigényessé vált,s ezt a megnövekedett tốkeigényt egyetlen tulajdonos, illetve egyazon tulajdonosi kör már gyakran nem tudja mozgósítani, helyette más tulajdonosi körrel rendelkező vállalat(ok) számára meghatározott tevékenységeket kiszerveznek. A külső partnerhez

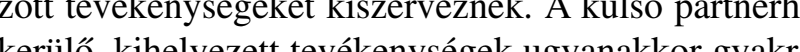
kerilo, kih lyeźct

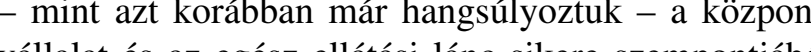
vritikus jesto

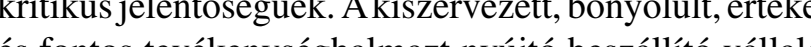
és fontos tevékenységhalmazt nyujtó beszallító vállal erớolénye ezért jelentósen nô, s ezzel párhuzamosa megnő a megrendelö, igénybe vevő vállalat függősesége és kiszolgáltatottsága is. Ennek az erőteljes függóség kapcsolatnak egy egyszerú, árversenyen alapuló, piaci szerződéssel támogatott, tehát piaci koordinációs mechanizmussal történő irányítása a megrendelő, központi vállalat szempontjából számos esetben igen kockázatos, ezért nem elképzelhetô. $\mathrm{S}$ ha nem is tud e központi válalat a tulajdon meoszerzése és így a bürokratikus koodinációs mechanizmus eszközével teljeskörúen élni, ez a koordinációs, irányit is eszkoz néhány saju

A bürokatiks ko meghatazón maz

illetve az azt lehetôvé tévớ tulajdonjog biztositáasanak szembetúnó eszköze a globális gazdaságban az ellátási láncban együttmúködó partnerek közötti kereszttulajdonlás erósödése. Ennek a kereszttulajdonlásnak a mértékét jellemzően a megrendelô szerepében lévő központi vállalat függóségének foka, illetve a kapcsolatban rejló kockázat szintje határozza meg. Minél erôteljesebb egy adott beszállítótól való függốség, s ezzel kockázatosabb az együttmúködés, annál magasabb lesz a tulajdonosi részesedés, melyet adott üzleti szituációban a központi válalat menedzsmentje használni tud, hiszen segítsévével a partnerek együttmúködését olyan irányba tudja terelni, mely saját érdekeinek megfelel.

Az ellátási lánc központi vállalatának tulajdonszerzését az ellátási lánc számára fontos együttmúködố partnereiben talán legismertebb, illetve legstrukturáltabb formában a japán autógyártó óriások, a Toyota, illetve a Nissan esetében tárták fel. A japán beszállít - autógyártó kapcsolatoknak három, eltéró tulajdonos részesedéssel jellemezhetố típusát különböztethetjii meg: a leányvállalatok, az ún. Takarakai Beszállít Társaságok és az ún. Shohokai Beszállítói Társaságo típusait (Dyer et al., 1998).
A leányvállalatok csoportjába tartoznak azok a eszállítók, melyekben az autógyártó jelentős - akár $00 \%$ is, de minimum 20\%-os - tulajdoni hányadda endelkezik. Ezek a beszállítók nagyon nagy értékû észegységeket gyârtanak, tôbbnyire az autogyártó gényeinek megfelelóen a testre szabás igen nagy fokával. A Takarakai Beszállítói Társaság vállalatai által gyártott termékek esetében is viszonylag magas testre szabásról beszélhetünk (7. ábra), de ebbe a csoportba számos függetlennek tekinthetố vállalkozás tartozik. A testre szabás nagy foka, illetve a kapcsolódó termékek közötti crős kölcsönös fïggósćg miatta megrendeló ko bezsal a beszalltokal, ezét jellemzon itt is megjelenik az jellón jellemzôn kevesebb mint 10\%. Vegul, de nem utolsósorban a Shohokai Beszâllítói Társaság már valamenynyi beszállító számára nyitott, a központi vállalat nem torrekszik tulajdonosi részesedés megszerzésére. Ezek a beszállítók többnyire standardizált tömegtermékeket állítanak elô, s ebboól adódóan a függőoség mértéke, a velük való együttmúködés kevésbé kockázatos, nem is igényli a tulajdonjogon alapuló bürokratikus koordinációs mechanizmus kiépítését.

Beszállító vállalatok csoportjai

7. ábra

(Dơlinációs mechanizmus alapján (Dyer et al., 1988)

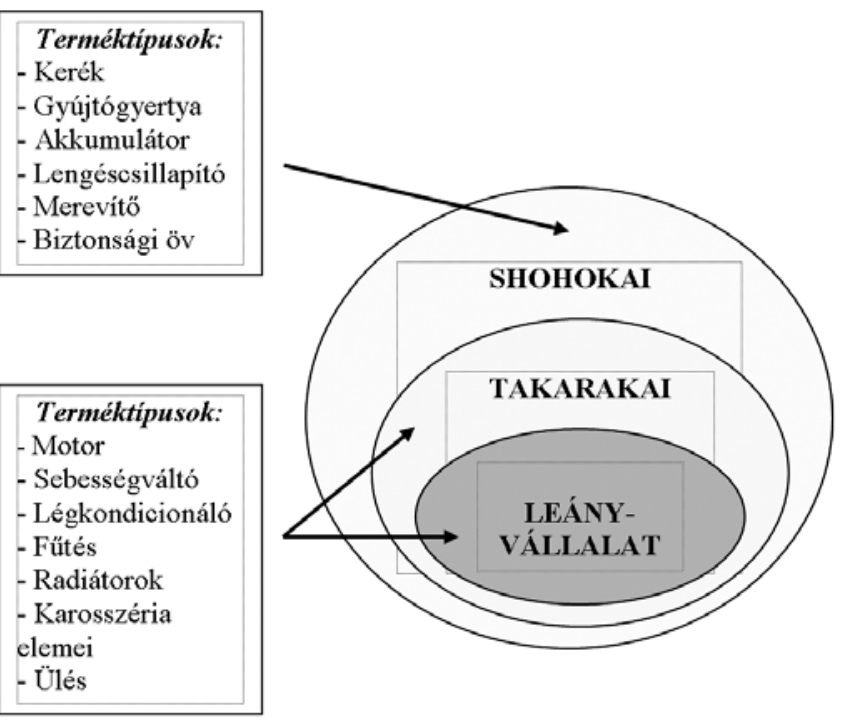

A hálózati múködés modelljének másik érdekessége a tranzakciós költségek elmélete âltal nem tárgyalt, gyanakkor nagy jelentôségú koordinációs mechanizmusnak, a Kornai (1983) által etikai koordinációnak nevezett koordinációs mechanizmus jelentőségének, zzerepének erôsōdése. Az etikai koordináció téma- 
köréhez kapcsolódóan az irodalom nagy hangsúllya tárgyalja a bizalomnak mint az ellátási láncban együttmúködő partnerek irányítási eszközének kérdéskörét. A bizalom mint irányítási eszköz és ezzel az etikai koordináció jelentőségének növekedése szintén összefügg a hálózati múködés modelljének jellemzóivel, elsősorban az együttmúköoó partnerek közötti függósség, és ebből adódóan az együttmúködésben rejló kockáza szintjének emelkedésével. A bizalomnak e kockázatalapú megközelítése szerint a bizalom azt jelenti, hogy az együttmúködés során az adott fél önkéntesen kockáaz egytúllal, s ebból fakadóan vállalja azt is, hogy sebezhetővé válik adott szituációban (Das - Teng, 2004 idézi: Nagy - Schubert, 2007).

Az egyes üzleti szituációk eltérô kockázati szinttel jellemezhetốk, s az egyes kockázati szinteken eltérô a bizalom mint irányitó, koordinációs eszköz jelentôsége is. Barney és Hansen (1994) három kockáza szintet, és ebból fakadóan három eltéró bizalmi igénynyel rendelkezó üzleti szituációt különböztet meg. Az alacsony kockázati szinttel jellemezhetó (pl. standard tömegtermékek gyártása esetén) üzleti szituáció eleve gyenge bizalmi igényư, a bizalomnak mint irányítási eszköznek nincs meghatározó jelentősége, az etikai koordináció helyett a piaci koordinációs mechanizmus, és ennek eszközei, a versenyeztetés, az ár és a szerződés lesznek a meghatározók. A nagy kockázatú együttm ködésk üzleti szituációk A natében a kapcsu együttm kodesek, hi leni szimuciok estén a kapcsolat bizal igénye elvileg nagy, de a kívánt viselkedés meglétét a felek nem bízzák pusztán erre az irányitásí eszközre, eróteljesen torekednek a tulajdonon alapuló, erós közvetlen iranyitási lehetóséget biztosító bürokratikus koordináció mechanizmusának kiépitésére. A két kockázati szint közötti átmeneti helyzetek, melyek

nyel számolhatnak ugyanakkor, melyek kockázatot rejtenek, azokat nem feltétlenül láthatnak és tudnak, vagy akarnak elôre szabályozni. Az ebből fakadó kockáza nem olyan mértékú, hogy az együttmúködó partnerek szükségesnek látnák tulajdonosi részesedés, és ezzel egy erôoteljes irányítási mechanizmus kiépítését, a bürokratikus koordinációs mechanizmus lehetőségének kialakítását. Egy közös, nagy sikerekkel kecsegtetố termék innovációja esetében például az új termék piaci sikerét, s ezen keresztül az innovációban részt vevố vállalatok versenyképességét alapvetốn befolyásolja az hogy egy kiüsó fél mennire jut hozzá az elót kutat́ś tán. khoz. Ennek elôfordulását a közös kutatásban rész véó vállalatok, illetve alkalnazottaik közôtti szerződésekkel nyilvánvalóan meg kívánják akadályozni; az is elképzelhetö, hogy az innováció gazdája az együittmúkôdó partner(ek)ben tulajdonosi részesedéssel bír alkalmazzák tehát mind a piaci, mind a bürokratikus koordináció mechanizmusát. Az is egyértelmú ugyanakkor, hogy az etikai koordináció és eszköze, a bizalom kiépítése nélkül a siker nem biztosítható.

Az együttmúködố partnerben való tulajdonosi részesedés mellett a kockázat kezelését a kapcsolatspecifikus befektetések mértékének emelésével is biztosítani lehet A kapcsolatspecifikus befektetések esetében olyan berus a colyan con 政 meg, smelyek mas kapesoluabanem, vagy csakjelentós értékvesztéssel vihetó át. Ezek tehát - természetesen a befektetés mértékétôl és azok kôlcsonôsségétôl függóen - rögzítik a kapcsolatot, nagyobb elkötelezettséget biztosítanak az együttmúködésben, $\mathrm{s}$ ily módon alapját képezik a bizalom kialakulásának is (1. táblázat).

1. táblázat (Bensaou, 1999)

\begin{tabular}{|l|c|c|}
\hline & Tárgyiasult beruházások & Nem tárgyiasult beruházások \\
\hline Beszállító & $\begin{array}{c}\text { Épuiletek, raktárak, létesítmény, berendezés típusa, a } \\
\text { megrendelóvel kompatibilis információs rendszer }\end{array}$ & $\begin{array}{c}\text { Beszállitó mérnökének az adott megrendelóvel } \\
\text { kapcsolatos tranzakció megismerésébe, } \\
\text { fejlesztésébe fektetett ideje, energiája }\end{array}$ \\
\hline Megrendeló & $\begin{array}{c}\text { Épületek, szerszámok, melyeket a megrendeló specifi- } \\
\text { kusan a beszállitóval való együttmúkoódés miatt hoz létre }\end{array}$ & $\begin{array}{c}\text { Munkatársak (pl. kutatók, mérnökök) } \\
\text { által a kapcsolatra fordított idó és energia }\end{array}$ \\
\hline
\end{tabular}

tehát közepes kockázattal jellemezhetó üzleti szituáci$o ́ k$, már eróteljesen építenek a bizalomra és az etika koordináció mechanizmusára. Ez a kockázat szintje szempontjából átmeneti helyzet valamilyen mértékben jellemzóen használja akár a piaci, akár a bürokratikus koordináció mechanizmusait. Az adott kapcsolat során az együttmúködó partnerek számos olyan körülmény-

A különböző üzleti szituációk igen sokfélék és folyamatosan változók, általában elmondható, hogy a kockázat növekedésével kezdetben nő a bizalom és az etikai koordináció jelentősége, legnagyobb szerepe a közepes kockázatú üzleti szituációkban figyelhetố meg, a kockázati szint további emelkedése ugyanakkor a bizalom és az etikai koordináció szerepének vissza- szorulásával jár együtt (8. ábra). Természetesen adott kapcsolat irányításakor a legtöbb esetben mindhárom említett koordinációs mechanizmus szerepet kap, a valóságban mindig a koordinációs mechanizmusok valamilyen kombinációja múködik.

Az üzleti szituáció kockázati szintje és a domináns koordinációs mechanizmus közötti kapesolat

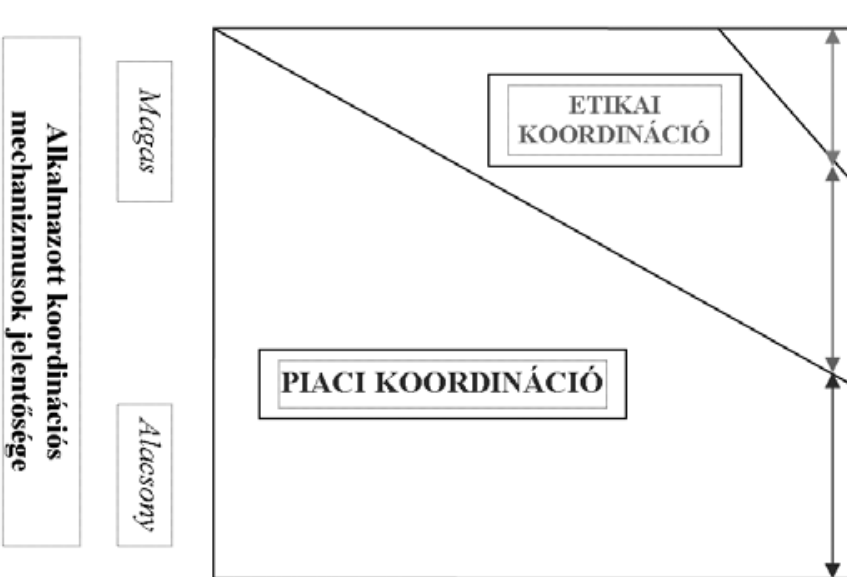

Alacsony
Ikalmazása adott pillanatban az üzleti hálózat egygy szereplójének kedvezólehet, hosszú távon mindeneppen negativ hatással van az üzleti hálózatok mási kiemelt épitoóelemének, az együttmúködó felek között kialakuló kapcsolatnak az alakulására. Gyengíti eze-
8. ábra ket a kapcsolatokat, szálakat, teljes negatív hatást fejtenek ki a hálózati sikert biztosító közös célt támogató koordinált, összehan ködés biztosításában!

$\mathrm{Az}$ eddigiekben meghatároztuk a modern gazdaság múködési egységének, az üzleti hálózatnak -, illetve az azt meghatározott szempon szerint leszúkítő - ellátási láncnak fogalmait, kialakulásuk módját és bemutattuk azokat a változásokat, melyek menedzsmentjük terén, a hálózatban együttmúködố partnerek irányítását biztosító koordinációs mechanizmusokban megfigyelhetók. A következókben az ïzleti hálózat

Az adott üzleti szituáció kockázati szzintj

Az eddig bemutatott és tárgyalt három koordiná- két kiemelt építókövéról, a hálózati ciós mechanizmus mellett Kornai (1983) tárgyal egy azaz a hálózat szereplőit, illetve a szálakról az együttnegyediket is, az agresszív koordinációs mechaniz- múködó partnerek között kialakuló kapcsolatokat szemust, hangsúlyozva, hogy a társadalmi kapcsolatok irányításában, azok kezelése során nincs ún. koord nációs vákuum, tehát amennyiben az elózóekben tá gyalt mechanizmusok egyike sem vezet eredményre, úgy a felek közötti viselkedést az agresszív koordinációs mechanizmus dönti el. Ez igaz az üzleti hálózatok, illetve az ellátási láncok kapcsolatainak kezelése, irányítása esetében is. Itt az agresszív koordináció eszköze az erófölény, mely számos forrásból származha A megrendelő erőfölényét egy adott beszállító vállabtA szemen biztosíthatja péld́ul a megrendelés ala ś́ga ennek a megrendelésnek a beszálító tés nagysága, enćk a nón volumenétín a vấ részesedesenek magas aranya. A beszállito is kenthet ugyanakkor erorolnybe, hiszen egy védett technológia, egy erós márkatermék jelentôse növelheti alkuerejét és pozícióját.

Az agresszív koordináció mechanizmusa minden bizonnyal a hálózati gazdaság esetében is megfigyelhető, teljes egészében nem kerülhetô el. Jellemzően az etikai koordináció múködési nehézségei, sérülése esetén, azt kiváltva jelenik meg. Fontos ugyanakkor hangsúlyozni, hogy bár ennek a koordinációs eszköznek az retnénk kissé részletesebben bemutatni.

\section{Az üzleti hálózat kiemelkedó építóeleme:}

\section{a hálózati szereplók}

A globális gazdaság metaszinten értelmezett szervezetének felépítésében meghatározó szerepe van a hálozatot alkotó vállalatoknak, szereplóknek. Az üzlet hálózat szereplóit, a hálózatot jellemzóen menedzseló központi vállalathoz füzódö viszony alapján három nagy csoportba sorolhatjuz

Az elsố csoportba az azonos tulajdonosi körrel endelkezô - az üzleti hálózat, illetve az ellátási lánc jellemzően központi vállalatának szerepét játszó - válleányvállalatai tartoznak. Az ebbe a vállalatacsoportba tartozó vállalatok belsố szervezeti felépítésének fejlôdése különböző utakat járhat be, mégis elmondható, hogy négy szervezeti, üzleti egység jellemzően része a csoportnak. Ezek a vállalati központ, a kutatás-fejegység. latcsoport, maga a transznacionális vállalat, illetve lesztési részleg, a termelés és a marketing-értékesítési 
A második csoportba az elsố kör szereplőivel együttmúködő, de azoktól tulajdonosi szempontból teljesen független vállalatokat soroljuk. Lehetnek modul, részegység-, sốt alapanyag-beszállítók, de különbözố - pl. pénzügyi, logisztikai szolgáltatások - beszállítói is. Ide soroljuk továbbá a központi vállalat független megrendelóit, illetve azok megrendelóit, illetve az értékteremtésben részt vevő kutatási, oktatási és egyéb szervezeteket.

Végül, de nem utolsósorban önálló szereplőtípust alkotnak azok a központi vállalattól kvázifüggetlen cégek, melyek esetében a hálózat központi vállalata

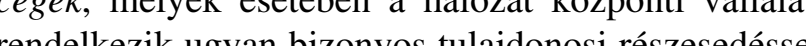
rendelkezk uy nem elegendó a kapcsolt egýcesedéssel, ez azonban nyításăhoz. Az ebbe a csoportba tartozó vállalatok és központi válalat kozôt jellemzôen mindkét fél részéről magas a kapcsolatspecifikus befektetések mértéke, $s$ az együttmúkoodés során a teljesen fuggetlen vállala ti körhöz képes eróteljesebb, a leányvállalati körhōz viszonyítva viszont gyengébb függő́séget, egymás utaltságot, s ebboól fakadoan irányítási lehetôséget biztosít. Ebbe a vállalati csoportba ugyanolyan típusú cégek kerülhetnek, mint a második pontban szereplók, lehetnek beszállítók, megrendelók, kutató és oktatási intézmények, illetve egyéb együttmúködó partnerek.

A szereplók bemutatása kapcsán részletesebben érdemes kitérni az elsố csoportba tartozó szervezeti, izzleti egységek ismertetésére Az első́c csoportba tartozo, jellemzóen transzacionális vállalat szervezeti egyse-

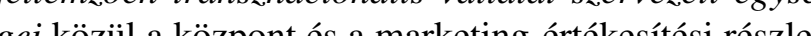
feladatai viszonyla fejlesztési, illetve a tegréri fejleszesi, illetve a tenmelési részleg esetében viszont már egymástól igen eltérớ tevékenységtartalomina bíró szervezetek alakulhatnak ki (Dicken, 2003).

A központ a vállalati irányítás magja, a stratégia döntéseket itt hozzák meg. Szerepe pénzügyi, finanszírozási szempontból is meghatározó, dönt az eróforrások egyes szervezeti egységek közötti felosztásáról. Ezen túl a központok szerepe meghatározó a vállalat egységei közötti információmegosztás és kommunikáció területén, de az üzleti hálózat (illetve ellátási lánc) egészének irányításában is. A transznacionális vállalati felépítésben elófordulhatnak regionális központok is melyek a vállalati központ és az egyéb szervezeti egységek között helyezkednek el, alapvető feladatuk, hogy a vállalati tevékenységet az adott régión belül integrálják. Szerepük gyakran vállalkozói jellegú, döntenek régió fejlesztéseiról, új kezdeményezéseiról.

A marketing-értékesitési részleg feladata a létrehozott termék- és szolgáltatáscsomag kapcsán követett értékesítési stratégia kialakítása és támogatása, az ezzel kapcsolatos erőforrás-allokáció biztosítása. Feladata kôzé tartozik továbbá az új vevókkel való kapcsolat építése, a meglévókkel való kapcsolat tartása, fejlesztése, a vevơi igények közvetítése a többi szervezeti egyg (kutatás-fejlesztés, illetve termelés) felé.

A kutatás-fejlesztési részleg szerepe a transznacionális vállalat esetében kiemelkedóen fontos. Fejlódése több fázison megy keresztül, s a szervezeti egység tevékenységének tartalma attól függ, hogy az adott szervezeti egység a komplex kutatás-fejlesztési folyamat mely részére koncentrál. Ezek szerint az adott szervezeti egység fókuszában - a komplexebb, illetve tudás- és tókeintenzívebbtól a kevésbé komplexek felé haladva az (1) alkalo zés (de - az (1) fejesztés, illetve (3) az uj temékterveige (dis igényekhez tôrténó igazítása álhat. A legalacsonyabb szintu K+F tevekenységet az ún. tamogató laboratórium végzi, melynek alapvetó célja az anyavállalat technologiajanak adaptalása, e folyamat támogatása a helyi piacokon. Megfeleltethetố az előzőekben bemutatott 3 . fázissal, $\mathrm{s}$ ez a leggyakrabban előforduló $\mathrm{K}+\mathrm{F}$ szervezeti egységek feladata. Az ún. helyileg integrált $K+F$ laboratórium már jelentösebb, a hozzá rendelt piac számára eredetinek számító termékinnovációt és fejlesztést hajt végre. Ez megfeleltethetô a 2. fázisnak. Az ún. nemzetközileg független $K+F$ laboratórium esetén lényeges kü̈lönbség hogy a teljes, integrál vállalatot kívánja t́́ loḱlis piaci iǵn tekét. Ennek ine lokális szervezeti egységekkel való kapcsolatrendszere igen szúkös, korlátozott.

A termékfókusz, és az ebból adódó konkrét tevékenységtartalom szempontjából négy jellemző terme lésiszervezet-típus, illetve ezek rendszere alakult ki. Ezek a globálisan centralizált termelóegység, a befogadó országra koncentráló termelés, egy regionális piacra történő termékspecializációval rendelkezó termelési szervezet, s végül a transznacionális szinten vertikálisan integrált termelési rendszer szereplôi (9. ábra).

a) A globálisan centralizált termelés esetén a termelést végzô szervezeti egység, létesítmény egy termék, illetve egy, a központ által meghatározott jellemzően szúk termókkör gýńt́́x́r specializálódik. A szóben

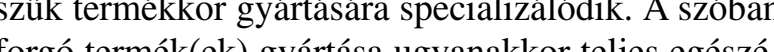

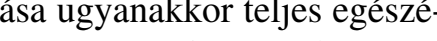
ben, globalis szinten egy szervezeti egységben, egy

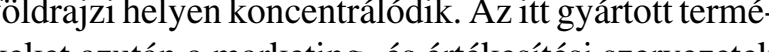
keket azután a marketing- és értékesítési szervezetek a világ valamennyi releváns piacain értékesítik.

b) A befogadó országra koncentráló termelés típusánál a termelési szervezetek termékpalettájuk kialakítása során a befogadó ország igényeihez igazodnak. Az egyes termelési egységek jellemzően több, a befogadó ország piaca szempontjából releváns terméket állítanak elô. Elsősorban azon országok és piacok esetében jellemzó, ahol a piac mérete jelentôs, a kereslet nagy, vagy a piaci igények nagyon egyedi vonásokat mutatnak

c) Az elmúlt negyven évben egy az előzőektól radikálisan eltéró termelésszervezési forma, és enne következtében új, speciális tartalommal bíró termelésiszervezet-típus is kialakult. Ez a megoldás egy racionalizált termék- és folyamatstratégia részeként jön létre, s célja egyes nagy regionális piacok (pl. EU, NAFTA) ellátása. Az adott régió országaiban egy-egy specializált, jellemzően szúk termékkörrel rend termékkörrel rendelkezố termelési létesítmény alakul ki, majd az ott gyártott termékeket a régió valamennyi országában értékesítik. E szervezeti megoldást nevezzük regionális piac szintjén kialakuló termékspecializációnak, s kialakulását és hatékony múködését a hatalmas belsố piac teszi lehetôvé. A termelési egységek földrajzi elhelyezkedését alapvetôen két tényezố közötti átváltás eredménye határozza meg: (i) a kevés számú termelólétesítménnyel elérhetô nagy méretgazdaságossági előny biztosítása, illetve (ii) sz összeszerééshez szïkséges inputok az osszeszereloshez szllikéges inputok mozgatásával, illetve a végtermék földrével kapeno

sével kapesolatos költségek alakulása.

A transznacionalis szinten vertikálisan integrált termelés esetében az egyes termelési folyamatra, illetve a végtermék szempontjaboól nézve beépülố részegységekre történő specializáció a meghatározó a termelés szervezeti egységeinek konkrét tevékenységtartalma szempontjából. Ma már a technológia

fejlődésének köszönhetően adott, komplex termék előállítása jól elkülöníthetố és jól kezelhetô részekre (modulokra, részegységekre és a hozź́juk tartozó termelési folyamokra) bontható. A techn tartofejlő́éssel púly fó jén ós és logisztika in egyes termelési folyamat szétbontásával elkülönült
termelési egységek közötti anyag- és információtermelési egységek közötti anyag- és információ-
áramlás gyors, pontos és rugalmas legyen. Ez azt is áramlás gyors, pontos és ngalmas legyen. Ez azt is lehetôvé teszi, hogy a nagy transznacionális vállala tok a termelési költségek régiónként megfigyelhetố különbözőségeiból adódó költségelőnyöket kihasználják, az egyes modulokat, részegységeket gyártó szervezeti egységeket más-más, egymástól akár földrajzilag igen messze fekvő szervezetekhez telepítsék.
A termék sikere szempontjából ugyanakkor kiemelkedóen fontos, hogy az így kialakult részegységeket loalito és beszallitó szzevezeti gysegeknek a belsố hálózatát hatékonyan múkoodtessék. Ebben az esetben a termelés és a piac közötti tradicionális kapcsola megszúnik. Egy adott ország termelési egységének outputja egy másik ország termelési egységének inputja lesz. A készterméket lehet, hogy egy harmadik országba exportálják, vagy akár a cég anyaországában értékesítik. Ezekben az esetekben a specializált termelőlétesítményt befogadó ország mintegy „exportplatformként" múködik (9. ábra). (Dicken, 2003 alapján)
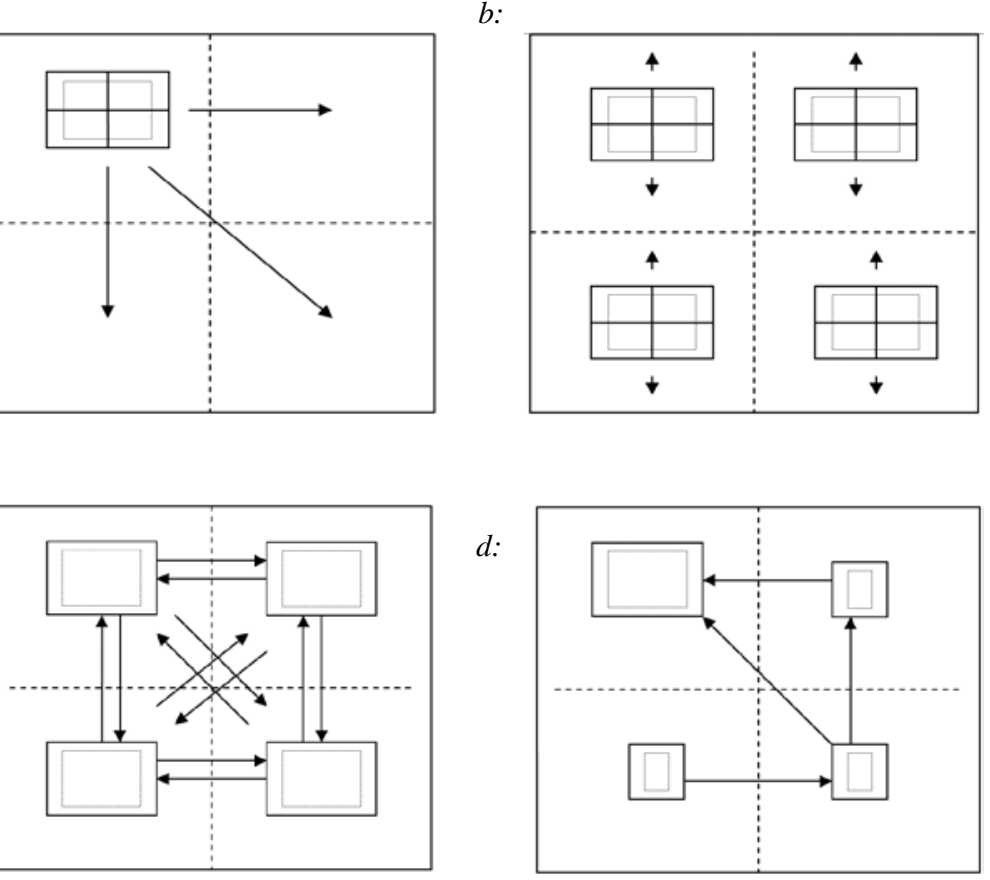

Az üzleti hálózatok e fejezetben bemutatott három ó szereplőtípusa (a jellemzóen transznacionális anyavállalat és leányvállalatai, a tóle teljesen független vállö̈ to

\section{Az üzleti hálózat másik építóeleme: a kapcsolatok}

Az üzleti hálózat szereplótípusai között három alapvetố kapcsolattípus - s ezek között számos átmeneti állapot - alakulhat ki. E fố kapcsolattípusok eltérố múködési jellemzókkel ${ }^{1}$ írhatók le, mely múködési jellemzók közvetlenül összefüggenek az együttmúködố felek közötti 
kockázat szintjével és ebból adódóan az adott kapcsolatban domináns, korábban bemutatott koordinációs mechanizmusokkal. A kapcsolatok között elsóként említjük az azonos tulajdonosi háttérrel rendelkezó, ún. bels ellátási hálózat szereplôi között megfigyelhető együttmúködést. A másik két fontos kapcsolattípus a központ vállalat szempontjából külső ellátási lánc tagokkal kialakított kapcsolat két kitüntetett típusa: az egymás számár kritikus fontosságú terméket vagy szolgáltatást biztosító felek között létrejövő ún. stratégiai partnerkapcsolat, letve az ún piaci cserekapcsolat, mely olyan együttmuködések esetén jellomzó, a

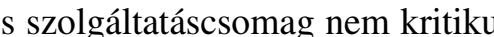
jelentőségú, a felek egymásra utaltsága ezért nem nagy.

\section{Kapcsolatok a belsố hálózatba}

A belsố üzleti hálózat tagjai, mint arról már vol szó, azonos tulajdonosi körrel rendelkeznek, irány tásukban az autoritáson, illetve utasításon alapuló bürokratikus koordináció a meghatározó. A közöttuik kialakuló kapcsolat irányítási struktúraja tehát adot. A kialakuló kapcsolatok tartalmát ugyanakkor nemcsak az alkalmazott koordinációs mechanizmus írja le, de fontos az is, hogy e belsổ üzleti hálózaton beliil milyen konkrét szervezeti megoldások, s ezzel milyen hatáskör- és felelősségmegosztás, illetve koordinációs hechanizs jo jönek létre. A belső elátís lációs,

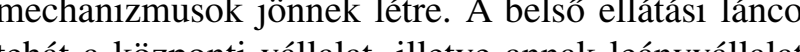
tehát a központ vallalat, illetve annak leányvállalat közöt kíalakuló szervezeti negoldások igen széles skálán nozog) egy Bantett és Goshal (1998, Bayer Czakó, 1999) egy három ideáltípusból álló tipológiấ javasol, melyet egy negyedikkel egészítenek ki. A szerzók hangsúlyozzák, hogy a negyedik szervezeti megoldás esetében még csak a kialakulás fázisáról beszéhetünk. A négy szervezeti megoldás az ún. nemzetközi szervezeti modell, az internacionális szervezeti modell, a globális szervezeti modell, illetve az integrált hálózati szervezeti modell (10. ábra).

1. A nemzetközi szervezeti modell jellemzően a két világháború közötti idôszakban jött létre, s gyakr a transzaciólis válatat jongerentil szervezer ja néven is emlegetik, mert a vallalatnak - illetve szervezeti egységeinek - világnéretú tevékenysége gyakorlatilag a nemzeti üzleti egységek portfóliójaként múködil. Minden nemzet egységnek meglehetósen nagy az önállósága, múkoodesúkben meghatározó a lokális orientáció. Jelentốs a felelôsségi körök és a jogkōrôk decentralizálása. A szervezeti megoldást egyszerú pénzügyi kontrollal és informális személyes koordinációval jellemezhetjük. A menedzsment a tengerentúli múködést, mint egymástól független egységek federációját képzeli el. Ebből következően gyorsan tud reagálni a helyi igények változására, de a meglehetốsen széttagolt szervezet nem támogatja a méretgazdaságossági előnyök kiaknázását és a hatékony tudásáramlást. Inkább az európai vállalatokra jellemzố szervezeti megoldás.

. Az internacionális szervezeti modell elsốként az 50-es és 60-as években, jellemzóen a nagy amerikai vállalatok tengerentúli terjeszkedése során alakult ki. E vállalatok növekedésükkel elsósorban marketingerejüket, technológiai vezetô szerepüket és vállalatspecifikus eszközeiket akarták hasznosita vála latspecifikus eszkozzeiket akarták hasznositani. Ena a szeco belfoldi nutködés kinyujtott karjaiként múködnek és erôsen építenek az anyavállalat, a központ tudásbázisára. S bár éppen a központban felgyulemlett tudás transzferenek a kihasználása a cél, a kialakuló szervezeti viszonyok jellemzóen jóval rugalmatlanabbak, mint az elózo formáció esetén. A központ a leányvállalatok múködését koordinált federációként értelmezi, az eszközök, felelősségi körök és döntések jelentő́s része decentralizált ugyan, de a központi kontroll (éppen az ott felhalmozott tudás miatt) erôteljesebb. Létezik formális tervezési eljárás, ahhoz kapcsolódó dokumentumok és ellenőrzési rendszerek, erốs a személyi függóség foka is.

Az 1900-as években már megjelenô múködési modell, a globális szervezeti modell (Ford és Rockefeller, illetve az 1970-es években a japánok használták eróteljesen) szerepe a gazdasági globalizáció felgyorsulásával nótt meg igazán. Az eszközök és elelősségi körök erôteljes centralizációja jellemzi, ahol a tengerentúli szervezeti egység feladata az, hogy elóállítsa, összeszerelje és piacra vigye a termékeket, de ennek során a vállalati központ által kialakított stratégiát, terveket és politikákat kell a leányvállalatoknak megvalósítaniuk. A leányvállalatok önállósága tehát erósen korlátozott mind az új termékek, mind az új stratégiák kidolgozásában, illetve a meglévő́k módosítáśb́n. A múködés fö célja

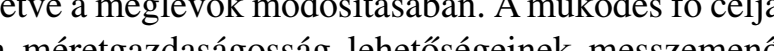
(aszemeno használása és a központban kialakított tudás és tapasztalat adaptálása, kihasználása. Ez gyakran együtt Jár a helyi piaci viszonyok figyelmen kívül hagyásával és a helyi tanulási lehetőségek kizárásával is. Mindhárom bemutatott szervezeti alaptípus megtalálható ma is. Ezek keveredésével további hibrid szervezeti megoldások is létrejöttek. Bartlett és Goshal hangsúlyozza, hogy a transznacionális vállalatok alapvetố dilemmája a mai igen gyorsan változó, turbulens környezeti feltételekhez történő rugalmas és öltséghatékony alkalmazkodás. Ennek biztosításá- hoz mindhárom szervezeti megoldás elônyös oldalainak kombinálására lenne szükségük, azaz egyszerre kellene biztosítani a gazdaságos múködést, a hatékonyságot, azaz a piaci ioényekhez való rugalmas akalmazkodást, és ehhez a világméretú tanulási folyamatokban rejló lehetőségek nagyfokú kiaknázását. Az erre történő törekvés új szervezeti megoldást, az integrált hálózat szervezeti modelljét hozta létre.

4. Az integrált hálózat szervezeti modellje esetében egy szétszórt hálózati konfigurációról beszélhetünk, mely jellemzóje, hogy rugalmas koordinációs folyam jokat képes kialokítani a szervezeti egyśóneközött. A hierarchikus irányítási és koordinációs mecoun. A heres mechanizo ció vâlja fel, és az adott probléna (pl. termékfejlesztés, kapacitásbő́vités, létesítmény elhelyezése) kapcsán kozos dontési mechanizmusok jellemzik. Cél a gyors információáramlás, a hatékony tudástranszfer mind a központ felól a leányvállalatok irányába, mind fordítva. Az így kialakuló struktúrát szokás heterarchikus struktúrának is nevezni (Dicken, 2003), ezzel hangsúlyozva a hierarchia hiányát a szervezetben, illetve ennek fontosságát a rugalmasság mint kritikus sikertényező biztosításában. A korábban tárgyalt szervezeti megoldások többsége erốteljesen épít a vállalati központ es sok tényvállala toü kätti hierarchikus viszont es a leány ám hierarchikus megözzelítés szerint lényeA tisztan hiench gében alá-folercencliség van közötuk, a leányvátlalatok egyszerúen végrehajtják a központ stratégáját és az ezzel kapcsolatban rájuk osztott feladato A heterarchikus viszony esetében viszont a közöttlik lévố kapcsolat sokkal összetettebb (10. ábra).

A transznacionális vállalatok belső üzleti hálózatának felépítése, $\mathrm{s}$ ennek kapcsán az adott országb települő leányvállalatok szerepe, önállóságának foka alapvetốen befolyásolja a befogadó ország gazdaságának múködését, illetve a befogadó országban tevékenykedô, a letelepülő́ leányvállalathoz csatlakozó, s ezzel a transznacionális vállalat üzleti hálózatának szerves a trászévé váló vállallalat uzzleti hálózatának szerves részévé váló vállalátok lehéóségeit. A leányvállala szerepét és lehetốségeit $-\mathrm{s}$ így a független partnerek
szerepét és lehetôségét is - alapvetóen meghatározzák szerepét és lehetőségét is - alapvetóen meghatározzák hálózat szereplói között kialakuló viszonyok.

Partnerkapcsolatok a külsó hálózatban

Az üzleti hálózat központi szereplője és a külso hálózat tagjai - beszállítók, megrendelók, egyéb szo gáltató vállalatok vagy éppen versenytársak - között kapcsolatok sokrétúek. E kapcsolatok tartalmát nem
A transznacionális vállalatok belsố

10. ábra i megoldás (Bartlett-Goshal, 1998; idézi Dicken, 2003)
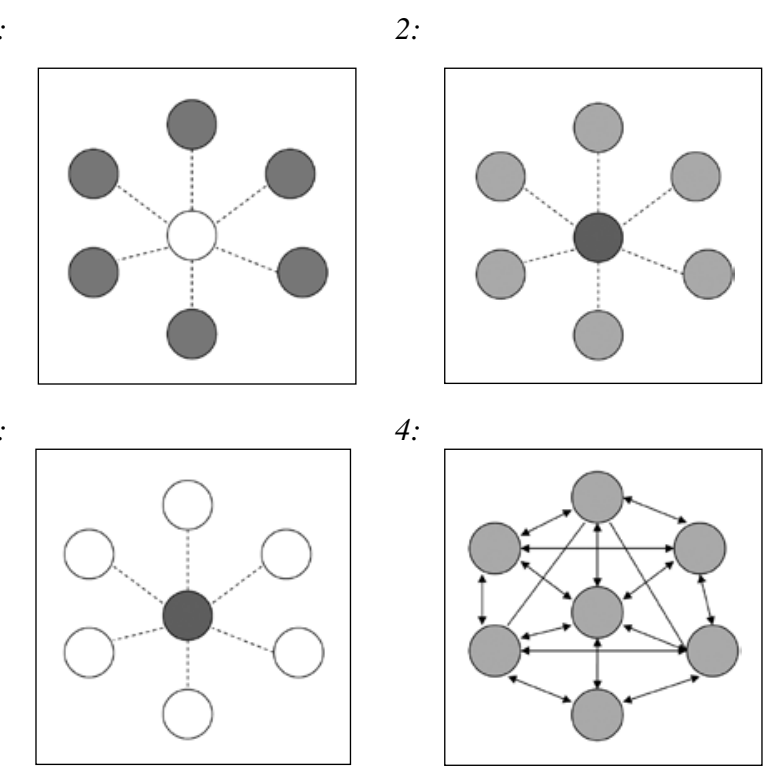

elsősorban a belső hálózatnál éló kapcsolatok számára releváns jellemzókkel (az érvényes feladat- és hatáskörmegosztással illetve, eoordináció és irányítás

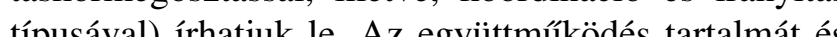

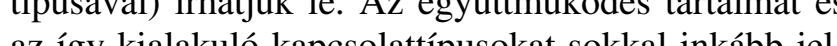
az igy kalakuló kapcsolán lenzi az egyuttmúkôdố felek kôzott megfigyelhetố

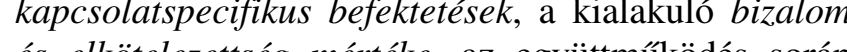
és elkotelezettség mértéke, az együtmúködés során megosztott informáciok kơre, a kôzösen végzett, a vállalati határokon túlnyúló tevékenységek aránya, a szerzódés hossza, végül a kizárólagosság foka (Dyer, 1996; Dyer et al., 1998; Bensaou, 1999). E múködési jellemzók mentén természetesen számos konkrét kapcsolattípus alakulhat ki. A valóságban minden kapcsolat más és más, a fenti jellemzók egymástól eltérố kombinációjával írható le. E sokszínúség ellenére ki kell emelni két kiemelkedố jelentőséoú, gyakran elóforduló kapcsolattípust, a piaci cserekapcsolat (szokták versenyour illetve a illetve a strategia partnerkapesolat (szokás egyszerúen A

A piaci cserekapcsolat mindkét együttmúködő fél részéról alacsony kapcsolatspecifikus befektetéssel jellemezhetô, ami kismértékú, kölcsönös függőségre utal. Az egymásrautaltság, s ebbő́l fakadóan a kockázat alacsony szintje miatt a bizalom szerepe nem kiemelkedő, s az információmegosztás során dominál a mindennapi múködés hatékony menedzsmentjéhez szükséges adatok, információk cseréje. Így az együtt- 
múködés során a megrendelố oldaláról jellemzô a osztásán túl egyéb, a versenyképesség szempontjából várható, majd a konkrét rendelési adatok, a rendelés- fontos, az egyes vállalatok számára klasszikusan érteljesítési feltételek (pl. határidő, kiszerelés) rendel- zékeny információk megosztása is. Ilyen információk kezésre bocsátása. Beszállítói oldalról ezek visszajelzése, a rendelésteljesítés állapotára vonatkozó adatok (esetleges késedelem mértéke, új határidő, esetleges termékhelyettesítés) megosztása elvárt és jellemzô. Ebben a kapcsolattípusban minimálisnak mondható az egymással együttmúköoő́ vállalatok között a vállalati határokat feszegetô, azokon túlnyúlóan végzett, közös tevékenységek aránya. Jellemző́en rövid tává szerződések megkötésére kerïl sor, melyek sikeres szeerudesk együttmikodes, a felek kölcsonons elégedettsége eseten - versenyeztetés után - ismét megköttethetnek, igy a piaci cserekapcsolat tipusaban is kialakulhatnak, kialakulnak hosszú élettartammal jellemezhetó kapcsolatok. Ugyanakkor nem jellemzó a kizárólagosság, egy-egy konkrét termék- és szolgáltatáscsomag cseréje kapcsán mind a megrendeló, mind a beszállító töb partnerrel múködhet együtt.

A stratégiai partnerkapcsolat esetében jellemzóen nagy és kölcsönös kapcsolatspecifikus beruházásoka találunk, hiszen a kölcsönös egymásrautaltság, így a függőség mértéke is nagy. A hatékony kapcsolat feltétele ezért a bizalom és az elkötelezettség nagy foka, és azok folyamatos fentart́s. Jellemző tovább́ a piaci cserekapcsolat esetében ismertetett információk meg-

A nagy autóipari hálózatok kapcsolatainak jellemzése

a termék végsố eladási pontján megfigyelhetố tényleges értékesítési adatok alakulása

az együttmúködő felek tényleges készlet- és kapacitásadatai,

érzékeny pénzügyi adatok

- a termék, illetve a technológia fejlesztése során nyert új adatok, információk,

stratégiai tervek, alkalmazott taktikák.

Jellemző továbbá erre az együttmúködési típusra a vállalati határokat feszegetó, közös cél érdekében végzett tevékenységek magas aránya. Az együttmúk öodés eltételeit rögzító szerződések a piaci cserekapcsolatoz kepest eleve hosszabb idôszakra köttetnek meg, s gyakori a felek közötti együttmúködés kizárólagossága, a megrendeló esetén az adott konkrêt termék- és szolgáltatáscsomag egy beszállítói forrásból való beszerzése, illetve fordítva, a beszállító részéról az egy, kizárólagos megrendelóvel való együttmúködés.

Dyer és szerzőtársai (1998) széles körú kérdőíves felmérésben vizsoálták meg az amerikai, a koreai és a japán autógyáttó vállalatok beszállítói kapcsolatainak (1)

2. táblázat (Dyer et al., 1998 alapján)

\begin{tabular}{|c|c|c|c|}
\hline & USA & Korea & Japán \\
\hline \multicolumn{4}{|c|}{ Kapcsolatspecifikus befektetések mértéke } \\
\hline A gyártelepek közötti távolság & Nagy & Kicsi & Szignifikáns különbség \\
\hline Azoknak a tókebefektetéseknek a mértéke, melyek nem átvihetók & Alacsony & $\begin{array}{l}\text { Szignifikáns } \\
\text { különbség }\end{array}$ & Szignifikáns különbség \\
\hline $\begin{array}{l}\text { Az együtt eltöltött munkanapok száma (pl. közös problémamegoldás, } \\
\text { koordináció) }\end{array}$ & Kicsi & Több & Szignifikáns különbség \\
\hline Vendégmérnökök száma & Alacsony & Alacsony & Szignifikáns különbség \\
\hline \multicolumn{4}{|c|}{ Információ megosztása / Támogatás } \\
\hline Annak mértéke, hogy a beszállitó bizalmas információkat is megoszt & Kicsi & Magasabb & Szignifikáns különbség \\
\hline Annak mértéke, hogy a beszállitío részletes költséginformációkat közöl & Közepes & Közepes & Szignifikáns különbség \\
\hline $\begin{array}{l}\text { Annak mértéke, hogy az autógyártó támogatást nyújt a beszállítónak a } \\
\text { költségcsökkentésben }\end{array}$ & Alacsony & Közepes & Közepes \\
\hline Annak mértéke, hogy az autógyártó segít a megfelelố minősség elérésében & Alacsony & Közepes & Közepes \\
\hline \multicolumn{4}{|c|}{ Bizalom / Szerzódések } \\
\hline $\begin{array}{l}\text { A beszállítói bizalom mértéke, miszerint az autógyártó fair lesz a } \\
\text { beszállitóval szemben }\end{array}$ & Közepes & $\begin{array}{l}\text { Kissé eró- } \\
\text { sebb }\end{array}$ & Erốs \\
\hline A szerző́dés átlagos hossza & $\begin{array}{l}\text { Szignifikáns } \\
\text { különbség }\end{array}$ & 3 év & 3 év \\
\hline
\end{tabular}

VEZETÉSTUDOMÁNY tokat, hogy saját múködési tapasztalatuk alapján jelöljék meg a két alapvetố kapcsolattípus (piaci cserekapcsolat, illetve stratégiai partnerkapcsolat) gyakoriság és értékeljék azokat az együttmúködés kiemelt jellemzói alapján (2. táblázat)

A 2. táblázatban közölt eredmények azt mutatták, hogy a nagy amerikai autógyártók beszállítói kapcsolatainak kezelése során jellemző a piaci cserekapcsolat dominanciája, míg a koreai partnerkapcsolatok domináns típusa a stratégiai partnerkapcsolat. A japán autógyártók ugyanakkor szegmentálják partnerkapcsolat ikyát s ṕrhuzamos a lát a piaci cserekapcsolat, illetve a stetén a piaci cserekapcsolat, illetve a stratégiai partnerkapcsolat jellemzôi szerint. A beszállítói hálozatnak ez

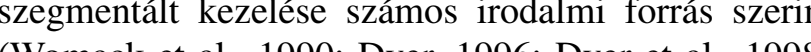
(Womack et al., 1990, Dyer, 1996, Dyer et al., 1998) a japán autogyártás sikerének egyik záloga, s ma $\mathrm{m}$ általánosan elfogadott menedzsmentalapelv.

A kutatás szerint tehát az amerikai autógyártó vállalatok jellemzóen piaci cserekapcsolatokat tartanak fen beszállítóikkal. Ennek eredményeképpen magas a kozös beszállítók száma. A beszállitó vállalatok esetében a több megrendelóvel fenntartott kapcsolat pozitív hozadéka, hogy beszállítók nagyméretúvé válhattak, és megvolt az a lehetóségük hogy tar a hogy tanuljanak a küloonbozzô megA koreai aúgyáń gyak A koreai autógyartók gyakorlata a másik végletet kepvisel E cégek megkövetelik beszállítóik nagyfokú lojalitását és kizárólagos beszállítást. Ennek eredményeképpen a beszállítók kapcsolatspecifikus befektetése magasak, és erôs a koordináció is az együttmúködő partnerek között. A kapcsolatoknak ez az exkluzivitása az autógyártók számára azzal az elônnyel jár, hogy az autógyáraz elônnyel jar, hogy az autogyártóknak a beszálituók fejlesztését célzó befekszeil gyưrüznek tovább más autógyártók felé. Ennek a gyakorlatnak az eredménye ugyanakkor az is, hogy a beszálitók kicsik maradnak, tehát a méretgazdaságosságból adódó elônyöket sem ók, sem megrendelőik nem tudják realizálni. Negatívum továbbá, hogy a kizárólagos kapcsolat a más megrendelőtól való tanulási lehetőséget is korlátozza.

- Versenyeztető viszony felé, - Nagy beszállitók -

- A partnerek k specializáció és

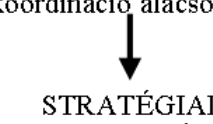
NINCS
A japán autógyártók voltak a beszállítók stratégiai szegmentációjában a leghatékonyabbak. A szegmentáció eredményeképpen a fúggetlen, inkább standard termékeket gyártó beszállítók érvényesíteni tudják a méretgazdaságosságból eredô előnyöket. Ezekbe a kapcsolatokba egyik fél sem fektet intenzíven, és alacsony a partnerek felé a tanácsadás, a támogatás szintje is, hiszen az így átadott tudás könnyen további szervezetekhez szivároghat át. Ezzel ellentétben, a stratégiai partnerkapcsolatban múködő vállalatok jelentős kapcsolatspecifikus beruházásokat hajtanak végre, illetve eróteljesen koosdińlják tevékenységïket partnerik( kel. Ez a koordinació gyakran olli a szemelyes megbeszćśs, egyeztetés for gyáát. Az autógyárto ugyanakkor

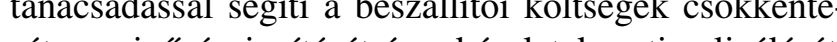
set, a minóség javíáátés a készletek optimalizalását Az autógyátónak érdeke is, hogy ezek a beszálitíók jól teljesítsenek, hiszen saját versenyképessége közvetlenül és erôteljesen függ tôlük. Vizsgálataik során a kutatók azt is megfigyelték, hogy a beszállítóknak ez a stratégiai szegmentálása nemcsak az elsố, de a második körös beszállítók esetében is kimutatható volt (11. ábra).

A nagy autógyártó nemzetek vállalatai esetében megfigyelhetố eltérő gyakorlat a beszállítói kapcsolatok kezelésében (Dyer et al., 1998 alapján)
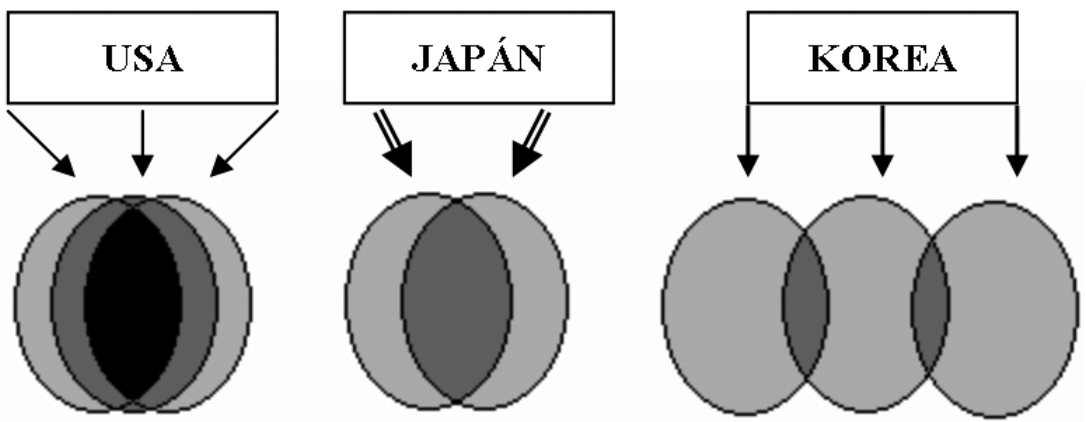
modell fennmaradt, de méretgazdaságosság
elōnyök

STRATÉGIAI
SZEGMENTÁCIO
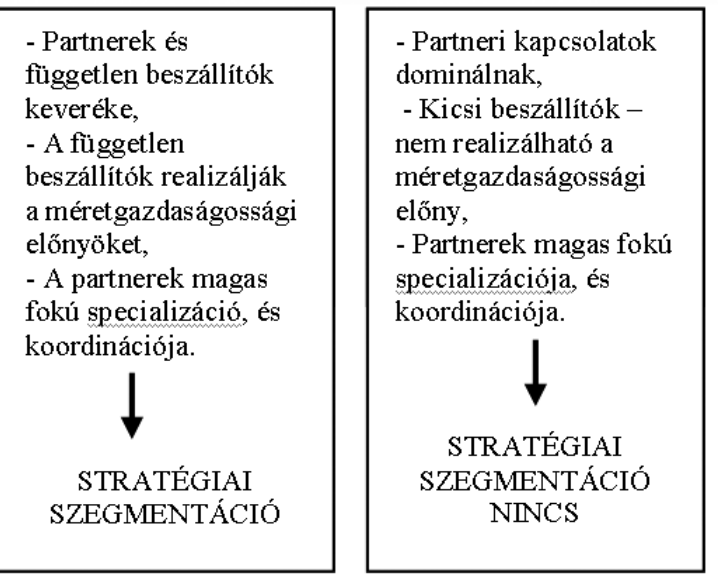

Az ábrán a kör mérete jelzi az adott autógyártó beszállítói körének nagyságát. A körök özötti átfedés (sötétebb rész) pedig mutatija a közös beszállítói kör méretét.

\section{VEZETÉSTUDOMÁNY}


A kutatás egyik legfontosabb üzenete szerint a beszállítók s az üzleti hálózat vizsgálata esetén általába az együttmúködó kapcsolatok stratégiai szegmentálásával tudja a központi vállalat biztosítani mindkét múködési modell elốnyeinek érvényre jutását. A szegmentálás egyik alapvetô szempontja, hogy milyen beszállitott termék fontossága: stratégiai vagy nem stratégiai jellegú. Stratégiai jellegú termékról beszélünk, ha a termék, illetve szolgáltatás nagy értéket képvisel, közel esik a megrendelố alapvetố képességéhez, jelentôsen hozzájárul a megrendeló termékének differencí́láśhoz (megkülönböztetéścz). Nem strat́g termékek azok melyek stán tern álnak, azaz a beszállitó-megrendeló kölcsonöös függó sége elóallitasuk sonn alacsony, ennek kovetkeztében eleve kicsi a partnerek kozotti koordinációs igény is. Alacsony ezeknél a termékeknél a kapcsolatspecifiku befektetések iránti igény, s a stratégiai termékekhez képest többnyire kisebb hozzáadott értéket képviselnek. Ennek következtében kevésbé tudják a végtermék költség/ár arányát befolyásolni.

Az adott, ideálisnak tekinthetố kapcsolat kialakítása szempontjából kiemelkedő fontosságú tehát a kapcsolatban a csere tárgyát képező termék, illetve szolgáltatás jellege. További fontos szempont a kapcsolatok szegmentálása során a beszállítói illetve a megrendel piac jellems oi az piac jellemzon az ott megfigyeho illetve a megrendelor múködoó felek képességei (Bensaou, 1999).

\section{Összefoglalás}

A tanulmány alapvetó célja az volt, hogy értelmezze az üzleti hálózatot és bemutassa annak felépítését, illetve múködési logikájának néhány kiemelt jellemzőjét. Mint az kiderültt, az üzleti hálózat, mint a globális gazdaság kváziszervezete, két kiemelt építóelemmel rendelkezik: a hálózat csomópontjain megtalálható szervezetekkel, üzleti egységekkel, illetve a közöttük kialakuló kapcsolatokkal. A tanulmány bemutatta mindkét énítóelem alapvetố típusait, azok kiemelt jellemzóit Í

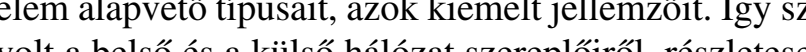
volt a belsớ és a kulsón hálozat szzereploirol, részletesen a belsó hálóza - a kozpont, jellemzóen transznacionális vállalat és leányvállalatainak - fobb formáiról. Fény derült az egyuttmunködô felek közôtti kapcsolattípusokra is, ismet kulôn a belsó és kulōn a kulsó ellátási lán esetében. Ezek segítségével árnyalt képet alkothatun az üzleti hálózat felépítéséról, struktúrájáról. A hálóza gazdaság múködési modellje változást hozott a gazdaságszervezés struktúrájába, de azok koordinációs, irányítási mechanizmusaiba is. Látható, hogy a hálózati gazdaság menedzsmentje során erősödik - ha speciális jegyeket felmutatva is - a bürokratikus, illetve az etikai koordináció szerepe. Remélhető, hogy azok a fogalmak, koncepciók, melyeket e tanulmány használt, segítséget nyújtanak globalizálodó gazdasági környezetünk megértésében, mely hosszú távon mind vállalataink, mind egész gazdaságunk versenyképessége szempontjából alapvetó fontosságú.

\section{Lábjegyzet}

A kapcsolattípusok leíŕsakor - mint a tanulmány korábbi részeiben is - a központi, jellemző́en transznacionális vállalat szempontjaból vizsgálódunk. A bemutatott kapcsolattípusok közül a természetesen nemcsak a központi vállalat és a vele egyä̈tmúr kơdó más vállalatok között alakulhat ki, de létrejöhet a központi vállalattól független, illetve kvázifüggetlen cégek között is.

\section{Felhasznált irodalom}

Bayer J. - Czakó E. (1999): A stratégiai vezetés sajátosságai a globalizáció közepette, Vezetéstudomány, 2. sz.

Barney, J.B. - Hansen, M.H. (1994): Trustworthiness as a source of competitive advantage, Strategic Managemen Journal, Vol. 15. Winter Special Issue, 175-190. old.

Bensaou (1999): Portfolios of Buyer-Supplier Relationships, Sloan Management Review, Summer,

országon (Az Ericsson, a Microsoft, az Elektrolux és a Knorr-Bremse példáján), Európai Tükör, 4. szám, 4162. old.

Chikán A. (1997): Vállalatgazdaságtan, Aula, Budapest Chikán, A. (2004): Vállalatgazdaságtan, Aula, Budapes

Choase, R.H. (1937): The Nature of the Firm; in: Williamson, O. E. - Winter, S. G. (ed.) (1991): The Nature of the Firm - Origins, Evolution and Development; Oxford University Press, Oxford

Das, T.K. - Teng, B.S. (1998): Between trust and control: developing confidence in partner cooperation in alliences; The Academy of Management Review, Vol. 23, No. 3, July, 491-512. old.

Dicken, P. (2003): Global shift - Reshaping the global economic map in the 21st century; SAGE Publications. London

Dyer, J.H. (1996): Specialized Supplier Networks as a Source of Competitive Advantage: Evido Industry, Strategic Management Journal, Vol. 17. 271-291. old.

Dyer, J.H. - Cho, D.S. - Chu, W. (1998): Strategic Supplier Segmentation: The Next „Best Practice” in Supply Chain Management, California Management Review, Vol. 40, No 2, Winter, 57-77. old.

Ford, D. - Gadde, L.E. - Håkansson, H. - Snehota, I. (2003): Managing Business Relationships, Second Edition, Wiley, New York
Gelei A. (2003): Az ellátási lánc típusai és menedzsmentkérdései, Vezetéstudomány, július-augusztus, 24-34. old Gelei A. (2007): Beszállítótípusok és azok alapvetó kompetenciái a hazai autóipari ellátási láncban, $\mathrm{PhD}-$ disszertáció, Budapesti Corvinus Egyetem, Gazdálkodástudományi Doktori Iskola

Gelei A.: A tevékenységmenedzsment tárgya, 2008; in: $D e$ meter K. - Gelei A. - Jenei I. - Nagy J. (2008): Tevékenységmenedzsment, Aula, Budapest

networks; in: Sorge, A. - Warner, M. (ed.) (1997): The IEBM handbook of organizational behaviour; International Thomson Business Plan, London, 232-240. old

Håkansson, H. - Ford, D. (2002): How should companies interact in business networks?, Journal of busines Research, Volume 55, Issue 2, February, 133-139. old.

Lambert, D.M. - Cooper, M.C. (2000): Issues in Supply Chain Management, Industrial Marketing Management; 29, 65-83. old.

Kohtamäki M (2006): Comparative case study on partnership and strategic network governance, IPSERA Annula Conference Preprint

Kornai J (1983): Bürokratikus és piaci koordináció, Közgazdasági Szemle, 3. szám
Laage-Hellman, J. (1997): Business networks in Japan supplier - customer interaction in product development, Routlege, London

Mentzer-DeWitt - Keebler - Min - Nix - Smith - Zacharia (2001): Defining Supply Chain Management, Journal of Business Logistics, Vol. 22, No. 2

(2007): A bizalom szerepe az üzlet kapcsolatokban, 77. sz. Múhelytanulmány, Vállalatgazdaságtan Intézet, Budapest

Porter, M. (1985): Competitive Advantage - Creating and Sustaining Superior Performance, The Free Press, New York Shary, P.B. - Skott-Larsen, T (2001): Managing the Global Supply Chain, Copenhagen Business School Press, Handelsh jskolens Forlag

E. (1998): Stratégiai szövetségek az üzleti világban, Közgazdasági és Jogi Könyvkiadó, Budapest New York

(1975): Markets and Hierarchies, Free Press, New York

Cikk beérkezett: 2008. 7. hó

Lektori vélemény alapján véglegesítve: 2008. 9. hó
KEDVES OLVASÓ!

KÉREM, NE FELEJTSE EL MEGÚJÍTANI

AZ EZ ÉVRE SZÓLÓ ELOÓFIZETÉSÉT! 